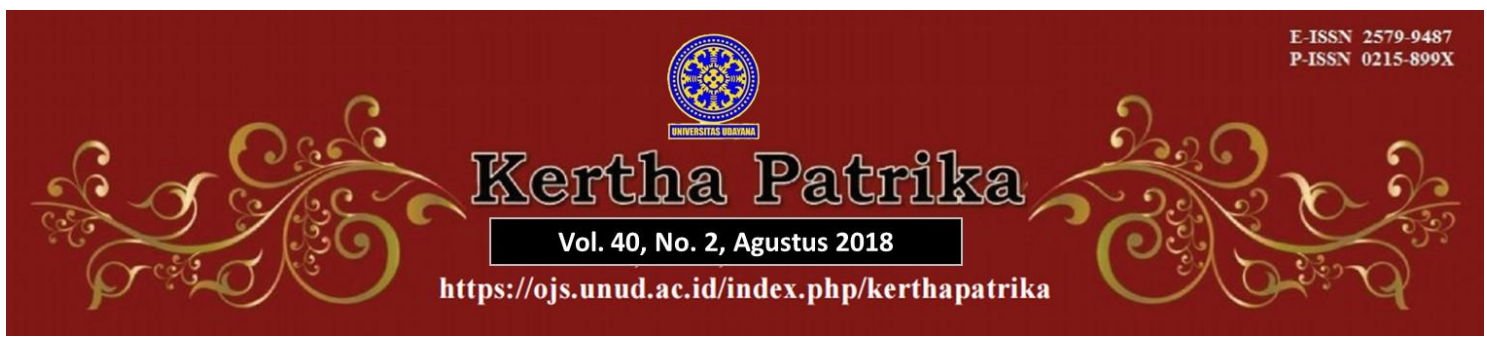

\title{
Status Kedudukan Anak dari Pembatalan Perkawinan Sedarah (Incest) Ditinjau dari UU No. 1 Tahun 1974 Tentang Perkawinan
}

\author{
Putri Maharani1
}

${ }^{1}$ Magister Kenotariatan, Universitas Airlangga, E-mail: p.maharani18@yahoo.com

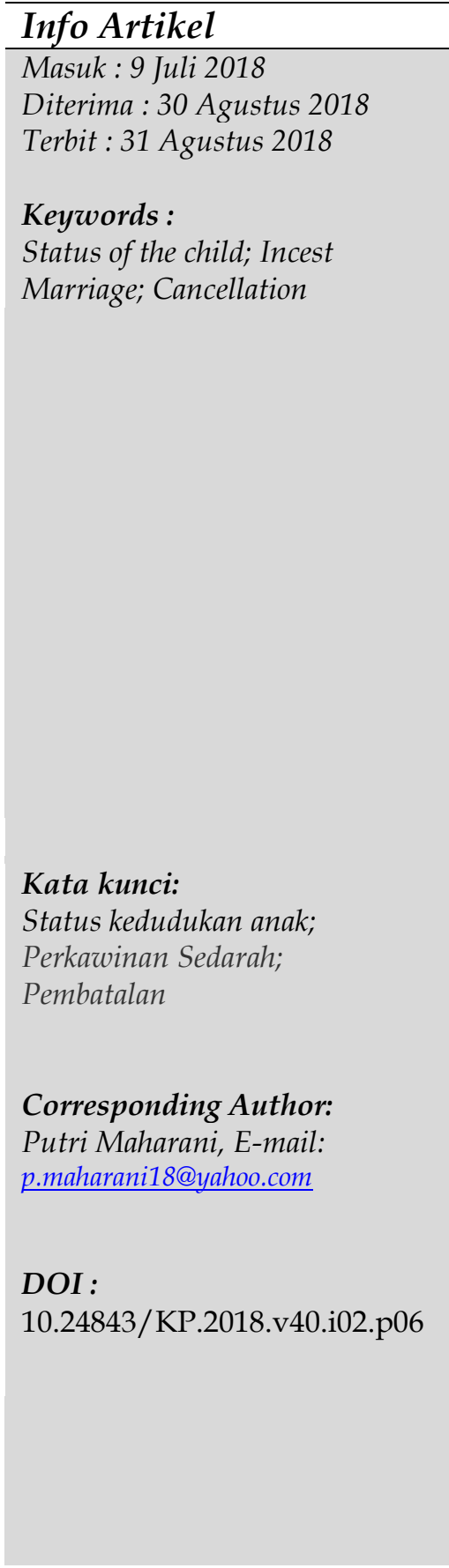

\begin{abstract}
Law No. 1 of 1974 Article 22 reads that Marriage may be canceled if the parties do not meet the requirements for marriage. One example is marriage in which there is a blood relationship between husband and wife. The problems studied in this study are: What is the status and position of the child from incest after the cancellation of marriage in view of Law No. 1 of 1974 About Marriage?. The research method used is the statute approach, case approach, comparative approach, and conceptual approach. While the objectives to be achieved in this study are: (1) To know how the status and position of the child from the cancellation of incest in accordance with Law No. 1 of 1974 About Marriage in Religious Courts of Yogyakarta. (2) Increase the Insight and Knowledge of the Author to study the law of Incest and marital status of the child from the result of incest in terms of Law No. 1 of 1974 on Marriage. Based on the result of the research of the verdict Number 216 / Pdt.G / 1996 / PA.YK in the Religious Court of Yogyakarta, it can be concluded that: in spite of the cancellation of marriage, the decision of the cancellation of marriage resulted in no retrograde to children born from the marriage.
\end{abstract}


1974 Tentang Perkawinan di Pengadilan Agama Yogyakarta. (2) Menambah wawasan dan pengetahuan Penulis untuk mempelajari hukum Perkawinan sedarah dan status kedudukan anak dari hasil perkawinan sedarah (incest) ditinjau dari Undang-Undang No. 1 Tahun 1974 Tentang Perkawinan. Berdasarkan hasil penelitian dari putusan Nomor: 216/Pdt.G/1996/PA.YK di Pengadilan Agama Yogyakarta dapat diambil kesimpulan bahwa: meskipun terjadinya pembatalan perkawinan, maka keputusan pembatalan perkawinan tersebut berakibat tidak berlaku surut terhadap anak-anak yang dilahirkan dari perkawinan tersebut

\section{Pendahuluan}

Perkawinan merupakan suatu hal yang penting dalam realita kehidupan umat manusia. Perseorangan maupun kelompok. Dengan jalan perkawinan yang sah, pergaulan laki- laki dan perempuan terjadi secara terhormat sesuai kedudukan manusia sebagai makhluk yang berkehormatan.

Allah berfirman bahwa manusia telah diciptakan oleh-Nya untuk berjodoh-jodoh atau berpasang-pasangan yang memungkinkan terjadinya perkembangbiakan, guna melangsungkan kehidupannya. Kebesaran Allah SWT dalam Al-quran dapat dilihat pada QS. An Nuur (24) : 32 dan QS. Adz Dzariyaat (51) : 49 yang artinya :

“Dan nikahkanlah orang-orang yang sendirian di antara kamu, dan orang-orang yang layak (menikah) dari hamba sahayamu yang lelaki dan hamba-hamba sahayamu yang perempuan. Jika mereka miskin Allah akan mengkayakan mereka dengan karunia-Nya. Dan Allah Maha Luas (pemberianNya) dan Maha Mengetahui. “ (QS. An Nuur (24) : 32). Menurut Undang-Undang Perkawinan terjadinya perkawinan memiliki tujuan yaitu untuk kebahagiaan suami istri, untuk mendapatkan keturunan dan menegakkan keagamaan, dalam kesatuan keluarga yang bersifat parental (keorangtua-an).

Suatu Perkawinan yang dapat dikatakan sah ialah perkawinan yang dilakukan menurut hukum masing-masing agamanya dan kepercayaannya. Apabila perkawinan dilakukan tidak sesuai dengan agama dan peraturan yang ada maka perkawinan tersebut dianggap tidak sah. Ketika perkawinan tersebut telah terjadi dan telah dilakukan akad nikah antara laki-laki dan perempuan maka timbul pula lah akibat-akibat dari perkawinan tersebut seperti adanya hak dan kewajiban antara suami dan istri, anak, serta timbullah akibat hukum terhadap harta benda yang diperoleh dari perkawinan tersebut.

Pada dasarnya, suatu perkawinan diharapkan agar dilakukan untuk waktu selamalamanya sampai mati oleh suami-istri, namun dalam keadaan tertentu ada hal-hal yang menghendaki putusnya perkawinan, artinya bila hubungan perkawinan tetap dilanjutkan, maka kemudharatan akan terjadi. Dalam hal ini, Islam membenarkan putusnya perkawinan sebagai langkah terakhir dari usaha melanjutkan rumah tangga sehingga dengan di putusnya sebuah perkawinan akan menjadi jalan keluar yang baik bagi dirinya maupun pasangan hidupnya. ${ }^{1}$

\footnotetext{
1 Syarifuddin, Amir, (2011), Hukum Perkawinan Islam di Indonesia (Antara Fiqh Munakahat dan
} 
Salah satu sebab putusnya perkawinan dapat dikarenakan fasakh, diatur dalam Pasal 22 Undang-Undang Nomor 1 Tahun 1974 yang berbunyi Perkawinan dapat dibatalkan apabila para pihak tidak memenuhi syarat-syarat untuk melangsungkan perkawinan. Adapun penyebab fasakh yaitu misalnya suami istri yang telah melangsungkan hidup perkawinan, tiba-tiba diketahui bahwa antara mereka terdapat hubungan saudara susuan, sejak diketahuinya hal itu, maka hubungan perkawinan mereka menjadi batal, meskipun misalnya telah mempunyai keturunan yang dipandang sebagai anak sah suami istri bersangkutan. Perkawinan itu dibatalkan karena tidak memenuhi syarat sahnya akad, yaitu tidak ada hubungan mahram antara laki-laki dan perempuan. ${ }^{2}$

Suatu perkawinan yang putus dan berakhir dikarenakan sebab fasakh atau adanya pembatalan perkawinan demi hukum yang dilakukan di depan sidang pengadilan salah satunya ialah kasus perkawinan sedarah (incest). Perkawinan ini jelas harus di batalkan sebab di dalamnya terdapat hubungan sedarah antara suami dan istri.

Perkawinan sedarah (incest) merupakan suatu perkawinan yang mana di dalamnya terdapat suatu pertalian keluarga antara mereka baik terhadap perempuan yang ada hubungan darah dalam garis keturunan ke atas, perempuan yang mempunyai hubungan darah dalam garis lurus ke bawah, saudara perempuan sekandung ayah atau seibu dan seterusnya ke atas, anak perempuan saudara laki-laki atau saudara perempuan saudara laki-laki atau saudara perempuan dan seterusnya ke bawah.

Salah satu contoh perkawinan sedarah yang terjadi di Indonesia ialah di Kota Yogyakarta, tepatnya di Kecamatan Tegalrejo. Pengadilan Agama Yogyakarta telah memutus pembatalan perkawinan sedarah dengan Nomor: 216/Pdt.G/1996/PA.YK. Perkawinan ini terjadi antara paman kandung dengan keponakannya yang semula menikah di KUA kecamatan Tegalrejo, Yogyakarta. Pernikahan ini terjadi akibat keluarga mempelai tidak mengetahui adanya larangan perkawinan keduanya dan ketika petugas KUA menanyakan ada tidaknya hubungan mahram, kedua keluarga mempelai memaparkan tidak ada. Perkawinan sedarah tidak hanya memancing perhatian kepada kedua pasangan, tetapi juga terhadap anak dari hasil perkawinan tersebut. Apabila dari perkawinan sedarah (incest) ini ternyata telah menghasilkan seorang anak, maka anak tersebut merupakan salah satu permasalahan yang akan timbul setelah adanya pembatalan perkawinan dari kedua orang tua nya, baik dari status, kedudukan, hak asuh hingga hak nafkah dari anak tersebut. Dengan adanya problematika-problematika diatas, maka permasalahan dalam penelitian ini adalah “Bagaimana status dan Kedudukan Anak dari Perkawinan Sedarah (incest) setelah adanya pembatalan perkawinan ditinjau dari Undang-Undang No. 1 Tahun 1974 Tentang Perkawinan ?".

Penelitian yang dilakukan mempunyai dua tujuan yaitu: (1) Tujuan Obyektif, untuk mengetahui bagaimana status dan kedudukan anak dari pembatalan perkawinan sedarah (incest) menurut Undang-Undang Nomor 1 Tahun 1974 Tentang Perkawinan di Pengadilan Agama Yogyakarta. (2) Tujuan Subyektif, untuk menambah wawasan dan pengetahuan Penulis untuk mempelajari hukum Perkawinan sedarah dan status kedudukan anak dari hasil perkawinan sedarah (incest) ditinjau dari Undang-Undang Nomor 1 Tahun 1974 Tentang Perkawinan.

Undang-Undang Perkawinan), Jakarta, Kencana, hlm 190

2 Ibid.,h. 77. 


\section{Metode Penelitian}

Jenis penelitian ini adalah yuridis normatif, yaitu penelitian kepustakaan adalah penelitian yang dilakukan dengan jelas mengumpulkan data sekunder yang terdapat dalam peraturan perundang undangan, yurisprudensi, putusan hakim, buku buku dan dokumen dokumen. Pendekatan dalam penelitian hukum bertujuan untuk memudahkan peneliti mendapatkan informasi yang berkaitan dengan masalah yang sedang dihadapi. Pendekatan-pendekatan yang digunakan antara lain pendekatan undang-undang (statute approach), pendekatan kasus (case approach), pendekatan konseptual (conceptul approach), pendekatan perbandingan (comparative approach). ${ }^{3}$ Secara umum jenis data yang diperlukan dalam penelitian adalah bahan hukum primer dan bahan hukum sekunder. Karena metode penelitian ini menggunakan yuridis normatif maka lebih mengutamakan data sekunder yaitu bahan bahan hukum seperti dokumen dan data terhadap kasus kasus yang digunakan sebagai penelitian. Sedangkan, analisis hasil penelitian merupakan suatu kegiatan yang berupa kajian atau telaah terhadap hasil pengolahan data dan atau bahan penelitian dengan kajian pustaka yang telah dilakukan sebelumnya. Analisis di sini menggunakan preskriptif yang mana sifat analisis ini dimaksudkan untuk memberikan argumentasi atas hasil penelitian yang telah dilakukannya. Argumentasi di sini dilakukan oleh peneliti untuk memberikan preskripsi atau penilaian mengenai benar atau salah atau apa yang seyogyanya menurut hukum terhadap fakta atau peristiwa hukum dari hasil penelitian.

\section{Hasil dan Pembahasan}

\subsection{Dasar Pertimbangan Hakim Dalam Memutus Perkara Pembatalan Perkawinan di Pengadilan AgamaYogyakarta}

Bahwa maksud dan tujuan permohonan pemohon adalah sebagaimana tersebut diatas;

Menimbang, bahwa Majelis telah berusaha memberi nasehat kepada pihak yang berperkara tetapi tidak berhasil dan Pemohon tetap mohon keputusan ;

Menimbang, bahwa Pemohon mengajukan permohonan ini berdasarkan antara Termohon I dan Termohon II telah melangsungkan pernikahan, padahal Termohon II adalah keponakan Termohon I (anak dari kakak kandung Termohon I) ;

Menimbang, bahwa Termohon I dan Termohon II membenarkan apa yang dikemukakan Pemohon, demikian juga orangtua dari Termohon II;

Menimbang, bahwa karenanya pernikahan yang telah dilangsungkan antara Termohon I dan Termohon II telah melanggar ketentuan Pasal 8 huruf b Undangundang No. 1 Tahun 1974 jo. Pasal 39 angka 1 Kompilasi Hukum Islam ;

Menimbang, bahwa sekalipun menurut hasil pemeriksaan pra nikah yang dilakukan PPN KUA Kecamatan Tegalrejo Kotamadia Yogyakarta semula menyatakan telah sesuai dengan prosedur yang berlaku namun ternyata kemudian ada hal-hal penting

${ }^{3}$ Marzuki, P,M. (2016), Penelitian Hukum Edisi Revisi. Jakarta : Prenadamedia Group.h.133. 
yang tidak disampaikan dengan sebenarnya baik oleh Termohon I dan Termohon II maupun pihak orang tua Termohon I I selaku wali dari Termohon II ;

Menimbang, bahwa Majelis perlu mengingatkan adanya Nash dari Kitab suci Al Qur'an surat An Nisa' ayat 23 ;

Menimbang, bahwa dengan demikian berdasarkan ketentuan pasal 174 HIR permohonan Pemohon terbukti menurut hukum oleh sebab itu dengan memperhatikan ketentuan Pasal 22, 23, 25 dan 28 Undang-undang No. 1 Tahun 1974 jo Pasal 37 dan 38 PP No. 9 Tahun 1975 jo. Pasal 70 huruf d, Pasal 73, 74, 75, dan 76 Kompilasi Hukum Islam maka patutlah untuk dikabulkan.

Menimbang, bahwa berdasarkan ketentuan Pasal 2 ayat 1 Keputusan Menteri Agama No. 162 Tahun 1988 Jo. Pasal 89 ayat 1 Undang-undang No. 7 Tahun 1989 biaya perkara dimohonkan kepada Pemohon ;

Mengingat, segala ketentuan perundang-undangan yang berlaku dan hukum syara' yang berkaitan dengan perkara ini.

\subsection{Status dan Kedudukan Anak dari Pembatalan Perkawinan Sedarah (Incest) Menurut Undang-Undang Nomor 1 Tahun1974}

Dari kasus yang terdapat dalam Putusan Nomor: 216/Pdt.G/1996/PA.YK ini sangat jelas bahwa perkawinannya telah melanggar syarat sah nya perkawinan yaitu tidak menjalankan suatu perkawinan menurut hukum agama dan kepercayaannya. Di dalam kasus tersebut perkawinan yang dilakukan antara Termohon I dan Termohon II merupakan perkawinan antar Paman dan Keponakan, yang artinya diantara keduanya masih memiliki hubungan darah. Oleh karena itu perkawinan yang dilangsungkan antara Termohon I dan Termohon II harus dibatalkan karena didalam perkawinan tersebut terdapat hubungan syara' yang mana terdapat hubungan mukhrim antara keduanya. Apabila perkawinan tersebut tetap dijalankan maka perkawinan tersebut dapat dikatakan sebagai suatu perkawinan yang tidak sah dan telah melanggar hukum.

Ketika suatu perkawinan sedarah (incest) yang dijalankan dan dilangsungkan sebelumnya dikarenakan para pihak tidak mengetahui bahwa adanya larangan perkawinan di antara keduanya, maka perkawinan tersebut dikatakan sebagai hubungan syubhat. Perkawinan antara keduanya tetap dianggap pernah terjadi dan sah saat itu, namun perkawinannya dianggap batal karena telah melanggar peraturan- peraturan tentang larangan perkawinan. Adanya itikad baik dapat ditentukan kalau yang bersangkutan pada saat perkawinan dilangsungkan tidak mengetahui adanya suatu rintangan perkawinan atau adanya suatu formalitas yang seharusnya dilakukan. Itikad baik subyektif; artinya di dalamnya tidaklah dipersoalkan apakah pihak yang bersangkutan sudah harus mengetahuinya. Bila kedua suami istri itu beriktikad baik dalam melangsungkan perkawinannya maka walaupun perkawinannya itu dibatalkan tetaplah perkawinan itu mempunyai akibatakibat yang sah terhadap mereka berdua dan anak-anaknya (Pasal 95 BW). ${ }^{4}$

Sedangkan, jika mereka telah mengetahui adanya larangan perkawinan diantara mereka namun tidak dilakukannya pembatalan perkawinan, maka perkawinan tersebut dianggap telah melanggar hukum. Pelanggaran yang dilakukan terhadap Pasal 8 Undang-Undang Perkawinan mengenai larangan-larangan perkawinan akan

\footnotetext{
${ }^{4}$ Soetojo Prawirohamidjojo, Asis Safioedin, (1986), Hukum Orang dan Keluarga, Bandung: Alumni, hlm. 39 .
} 
batal dengan sendirinya. Pada saat itu juga perkawinan batal secara hukum, artinya perkawinan tersebut telah batal dan rusak dengan sendirinya sehingga haram untuk diteruskan dan melakukan persetubuhan.

Pembatalan perkawinan dapat diajukan oleh pihak-pihak yang telah diatur pada Pasal 23 Undang-Undang Nomor 1 Tahun 1974 dan Pasal 73 KHI. Suatu perkawinan dapat dianggap batal dimulai setelah adanya keputusan Pengadilan yang mempunyai kekuatan hukum tetap, dan berlaku sejak saat berlangsungnya perkawinan, hal ini termuat di dalam Pasal 28 ayat (1) Undang-Undang Nomor 1 Tahun 1974. Keputusan ini tidak ada upaya hukum lagi untuk naik banding atau kasasi. Akibatnya, kembali ke posisi semula sebelum terjadinya perkawinan, atau perkawinan dianggap tidak pernah ada perkawinan yang putus demi hukum, maksudnya karena perkawinan tersebut putus dengan sendirinya tetapi, bukan dengan sendirinya seperti karena kematian yang sifatnya alamiah.

Perkawinan sedarah yang sebelumnya telah terjadi tidak diketahui terdapat larangan perkawinan, dan setelah diketahui, maka perkawinan tersebut harus segera dibatalkan. Karena banyak dampak negatif yang dihasilkan dari perkawinan sedarah itu sendiri, terutama dampak yang paling buruk dari hasil perkawinan sedarah tersebut ialah anak yang dilahirkan dari perkawinan tersebut. Dampak buruk tersebut meliputi dari kesehatan, dan kondisi fisik anak tersebut hingga status dan kedudukan anak tersebut kelak.

Perkawinan yang telah dibatalkan tentunya memiliki akibat-akibat hukum setelah adanya pembatalan perkawinan seperti status istri maupun suami, harta bersama, status dan kedudukan anak, hingga pemeliharaan anak. Undang-undang sangat memperlunak akibat hukum pembatalan perkawinan ini sehingga perkawinan itu tetap mempunyai akibat; baik terhadap suami istri dan anak-anaknya maupun terhadap pihak ketiga sampai pada saat pernyataan pembatalan itu.

Akibat dari adanya pembatalan perkawinan ini telah diatur secara jelas di dalam Undang-Undang Nomor 1 Tahun 1974 Pasal 28 Ayat (2) dinyatakan:

Keputusan tidak berlaku surut terhadap:

a. Anak-anak yang dilahirkan dari perkawinan tersebut

b. Suami atau istri yang bertindak dengan beritikad baik, kecuali terhadap harta bersama, bila pembatalan perkawinan didasarkan adanya perkawinan lain yang lebih dahulu.

c. Orang-orang ketiga lainnya tidak termasuk dalam huruf a dan b sepanjang mereka memperoleh hak-hak dengan itikad baik sebelum keputusan tentang pembatalan mempunyai kekuatan hukum tetap.

Di dalam Hukum Islam ada beberapa perbedaan dari ketentuan Undang-Undang Nomor 1 Tahun 1974. Di dalam KHI seperti yang terdapat pada Pasal 75 dan 76 menjelaskan:

Keputusan pembatalan perkawinan tidak berlaku surut terhadap:

a. Perkawinan yang batal karena salah satu dari suami istri murtad;

b. Anak-anak yang dilahirkan dari perkawinan tersebut;

c. Pihak ketiga sepanjang mereka memperoleh hak-hak dengan beriktikad baik, sebelum keputusan pembatalan perkawinan mempunyai kekuatan hukum yang tetap.

Pasal 76 KHI juga menambahkan pernyataan yang berbunyi:

Batalnya suatu perkawinan tidak akan memutuskan hukum antara anak dengan orang tuanya.

Menurut Undang-Undang Nomor 1 Tahun 1974 Pasal 42, anak sah ialah anak yang 
dilahirkan dalam atau sebagai akibat perkawinan yang sah.

Pada putusan Nomor: 216/Pdt.G/ 1996/ PA.YK telah dijelaskan bahwa dari perkawinan yang telah dibatalkan antara Termohon I dan Termohon II telah menghasilkan dua orang anak. Definisi anak sah dalam aturan perundang-undangan adalah sebagai berikut : Pasal 42 UU Perkawinan menyebutkan bahwa anak sah adalah anak yang dilahirkan dalam atau sebagai akibat perkawinan yang sah. ${ }^{5}$ Terhadap anak-anak yang dilahirkan di dalam perkawinan yang sah sebelum perkawinan tersebut dibatalkan karena ketidaktahuan kedua belah pihak maka statusnya disebut sebagai anak sah. Hubungan hukum keperdataan yang disebabkan kelahiran dari perkawinan yang sah, dengan kata lain sebab hukum dalam sebuah nasab yaitu terletah pada hubungan biologisnya bukan pada perkawinannya. ${ }^{6}$ Anak yang lahir dari perkawinan yang sah, maka anak tersebut mempunyai ibu dan bapak tetapi jika lahir diluar perkawinan yang sah hanya mempunyai hubungan darah dengan ibunya.7 Frasa "di luar perkawinan" sangat berbeda maknanya dengan frasa "tanpa perkawinan" anak yang dilahirkan diluar perkawinan atau anak yang lahir dari perkawinan yang dilakukan sesuai dengan ketentuan agama dan kepercayaannya tapi tidak tercatat pada KUA atau Kantor Catatan Sipil merupakan anak yang sah secara materiil tapi tidak sah secara formil. Sedangkan anak yang dilahirkan tanpa perkawinan orang tuanya atau anak yang dilahirkan dari hubungan antara lelaki dengan prempuan tanpa adanya ikatan perkawinan merupakan anak yang tidak sah secara materiil juga tidak sah secara formil (anak zinah). ${ }^{8}$ Ketika perkawinan kedua orang tua nya di batalkan maka kedudukan anak tersebut baik dalam hak mewarisi hingga hak nafkah tetap berkaitan dan menjadi kewajiban ayah dan ibunya. Pembatalan perkawinan tidak menjadi sebab berubahnya status hak waris anak. Ini dikarenakan ketika terlahirnya anak tersebut, kedua pihak belum mengetahui apabila perkawinan mereka telah melanggar syara' dan harus dibatalkan.

Kecuali, ketika kedua pihak telah mengetahui bahwa terdapat perkawinan mereka telah melanggar syara' dan harus dibatalkan, namun mereka tetap menjalankan perkawinan tersebut dan tidak melakukan pembatalan perkawinan, maka perkawinan tersebut menjadi perkawinan yang melanggar hukum dan status anak yang dilahirkan adalah tidak sah. Sehingga anak yang dilahirkan hanya memiliki kedudukan baik dari hak mewarisi hingga hak nafkah hanya pada ibu kandung dan keluarga ibu saja.

Obyek perlindungan hukum adalah hak -hak hukum seseorang. Hak mengandung pengertian milik, kepunyaan, wewenang atau kekuasaan untuk berbuat sesuatu yang ditentukan oleh hukum. Perlindungan hukum adalah proses, perbuatan dan cara

${ }^{5}$ Hidayat, I. (2017). Suatu Telaah Tentang Keberadaan Anak Sumbang Dalam Mewaris Di Lihat Dari Aspek Hukum Adat. Jurnal Ilmiah Universitas Batanghari Jambi, 15(1), 40.

${ }^{6}$ Fure, A. A. (2016). KEDUDUKAN ANAK AKIBAT BATALNYA PERKAWINAN KARENA HUBUNGAN DARAH MENURUT HUKUM POSITIF. LEX PRIVATUM, 4(3),44.

${ }^{7}$ Larasati, F. C, Sugijono, \& Adonara, F. F (2013). Hak Waris Anak Incest Terhadap Harta Orang Tua Biologisnya (Incentuous child's Inheritance Rights For Property of Their Biological Parents). Universitas Jember, Fakultas Hukum Jember.h. 2.

8 Rasyid, Chatib. (2012). Anak Lahir Diluar Nikah (Secara Hukum) Berbeda Dengan Anak Hasil Zina, Kajian Yuridis Terhadap Putusan MK No. 46/ PUU-VIII/2010. Seminar Status Anak Diluar Nikah dan Hak Keperdataan Lainnya, h. 5 
hukum melindungi hak, kepunyaan, wewenang atau kekuasaan seseorang. ${ }^{9}$ Dalam hal pemeliharaan anak pun, Undang-Undang Nomor 1 Tahun 1974 telah mengatur nya di dalam Pasal 45 ayat (1) dan (2), yaitu kedua orang tua wajib memelihara dan mendidik anak-anak mereka sebaik-baiknya. Kewajiban tersebut berlaku sampai anak itu dapat berdiri sendiri, kewajiban mana berlaku terus meskipun perkawinan antara kedua orang tua putus. Telah diatur pula didalam Pasal 156 huruf

(a) dan (b) KHI mengenai hak asuh terhadap anak akibat putusnya suatu perkawinan, yaitu:

a. Anak yang belum mumayyiz berhak mendapatkan hadhanah dari ibunya, kecuali bila ibunya telah meninggaal dunia, maka kedudukannya digantikan oleh:

(1) wanita-wanita dalam garis lurus ke atas dari ibu;

(2) ayah

(3) wanita-wanita dalam garis lurus ke atas dari ayah;

(4) saudara perempuan dari anak yang bersangkutan;

(5) wanita-wanita kerabat sedarah menurut garis samping dari ayah;

b. Anak yang sudah mumayyiz berhak memilih untuk mendapatkan hadhanah dari ayah atau ibunya;

\section{Kesimpulan}

Berdasarkan hasil studi kasus Putusan Pengadilan Agama Yogyakarta Nomor : 216/Pdt.G/1996/PA.YK, maka dapat diambil kesimpulan bahwa anak yang dihasilkan dari perkawinan sedarah (incest) yang terjadi akibat ketidaktahuan bahwa perkawinannya telah melanggar larangan perkawinan tetap menjadi anak yang sah. Sebab, anak tersebut dilahirkan di dalam perkawinan yang sah, dan awalnya perkawinan tersebut dilakukan dengan iktikad yang baik pula sebelum diketahui telah terdapat larangan perkawinan. ketika kedua pihak telah mengetahui bahwa terdapat perkawinan mereka telah melanggar syara' dan harus dibatalkan, namun mereka tetap menjalankan perkawinan tersebut dan tidak melakukan pembatalan perkawinan, maka perkawinan tersebut menjadi perkawinan yang melanggar hukum dan status anak yang dilahirkan adalah tidak sah. Sehingga anak yang dilahirkan hanya memiliki kedudukan baik dari hak mewarisi hingga hak nafkah hanya pada ibu kandung dan keluarga ibu saja. Pembatalan perkawinan tidak menjadi sebab berubahnya status hak waris anak, serta dalam hal pemeliharaan anak, pembatalan perkawinan tetap membebankan kewajiban pemeliharaan kepada kedua orang tua nya secara seimbang.

9 Tektona, R. I. (2013). Kepastian hukum terhadap perlindungan hak anak korban perceraian. Muwâzâhh, 4(1),23. 


\section{Daftar Pustaka}

$\underline{\text { Buku }}$

Marzuki, P,M. (2016), Penelitian Hukum Edisi Revisi. Jakarta : Prenadamedia Group.]Prawirohamidjojo, Soetojo \& Asis, Safioedin.(1986). Hukum Orang dan Keluarga, Bandung: Alumni. h.39.

Rasyid, Chatib. (2012). Anak Lahir Diluar Nikah (Secara Hukum) Berbeda Dengan Anak Hasil Zina, Kajian Yuridis Terhadap Putusan MK No. 46/ PUU-VIII/2010. Seminar Status Anak Diluar Nikah dan Hak Keperdataan Lainnya

Syarifuddin, Amir. (2011). Hukum Perkawinan Islam di Indonesia (Antara Fiqh Munakahat dan Undang-Undang Perkawinan). Jakarta : Kencana.

\section{Jurnal}

Fure, A. A. (2016). KEDUDUKAN ANAK AKIBAT BATALNYA PERKAWINAN KARENA HUBUNGAN DARAH MENURUT HUKUM POSITIF. LEX PRIVATUM, 4(3).

Hidayat, I. (2017). Suatu Telaah Tentang Keberadaan Anak Sumbang Dalam Mewaris Di Lihat Dari Aspek Hukum Adat.Jurnal Ilmiah Universitas Batanghari Jambi, 15(1).

Larasati, F. C, Sugijono, \& Adonara, F. F (2013). Hak Waris Anak Incest Terhadap Harta Orang Tua Biologisnya (Incentuous child's Inheritance Rights For Property of Their Biological Parents). Universitas Jember, Fakultas Hukum Jember.

Tektona, R. I. (2013). Kepastian hukum terhadap perlindungan hak anak korban perceraian. Muwâzâhh, 4(1).

Internet

Andtheem, Dampak Resiko Akibat Perkawinan Sedarah. 09 Oktober 2011, http://andtheem.blogspot.co.id/2011/dampak-resiko-akibatpernikahan- sedarah-html.

Anonim, Bahaya Pernikahan Sedarah,. 08 Juli 2012. http://www.klikdokter.com/tanyadokter/seks-andrologi/23830$\underline{\text { bahaya:pernikahan- sedarah, }}$

\section{Peraturan Perundang-undangan}

Kitab Undang-Undang Hukum Perdata (BW)

Undang-Undang Nomor 1 Tahun 1974 tentang Perkawinan, (Lembaran Negara Republik Indonesia Nomor 1 Tahun 1974)

Peraturan Pemerintah Nomor 9 Tahun 1975 Tentang Pelaksanaan Undang-Undang Nomor 1 Tahun 1974 Tentang Perkawinan, (Lembaran Negara Republik Indonesia Nomor 12 Tahun 1975). 